\title{
Protection of Steel Using Aluminum Sacrificial Anodes in Artificial Seawater
}

Tai-Ming Tsai

Lecturer, Department of Marine Engineering and Technology, National Taiwan Ocean University, Keelung, Taiwan 20224, R.O.C.

Follow this and additional works at: https://jmstt.ntou.edu.tw/journal

Part of the Engineering Commons

\section{Recommended Citation}

Tsai, Tai-Ming (1996) "Protection of Steel Using Aluminum Sacrificial Anodes in Artificial Seawater," Journal of Marine Science and Technology: Vol. 4: Iss. 1, Article 12.

DOI: $10.51400 / 2709-6998.2545$

Available at: https://jmstt.ntou.edu.tw/journal/vol4/iss1/12

This Research Article is brought to you for free and open access by Journal of Marine Science and Technology. It has been accepted for inclusion in Journal of Marine Science and Technology by an authorized editor of Journal of Marine Science and Technology. 


\section{Protection of Steel Using Aluminum Sacrificial Anodes in Artificial Seawater}

Acknowledgements

The author is grateful to Professor J. K. Wu for his kindness instruction in these years, and also thanks for his counseling in this paper. 


\title{
PROTECTION OF STEEL USING ALUMINUM SAC- RIFICIAL ANODES IN ARTIFICIAL SEAWATER
}

\author{
Tai-Ming Tsai*
}

Keywords: sacrificial anode, cathodic protection, corrosion.

\section{ABSTRACT}

The performance of aluminum alloys used as sacrificial anodes for cathodic protection in seawater was investigated in this study. Results show that A1 -3.5\% Zn-0.05\%In sacrificial anode alloy $C$ has the best current efficiency, most negative open circuit potential and energy characteristics among five different Al-ZnIn alloys. Polarization curve of alloy $\mathrm{C}$ also shows no passivation behavior in artificial seawater. The corrosion rate of mild steel in artificial seawater was determined as a function of applied cathodic potential. The cathodic protection potential determined for mild steel in seawater was $-0.78 \mathrm{~V}, \mathrm{SCE}$ for a corrosion rate of less than $1 \mathrm{mpy}$. The protective area ratio of steel to sacrificial anode has been measured. Steel can be protected under the area ratio up to $4000-5000$

\section{INTRODUCTION}

The corrosion protection of marine equipments and offshore structures can be provided by sacrificial anodes or an impressed current cathodic protection system. The protection by sacificial anodes, although it costs generally more than that by means of an external current source, is preferred for offshore use due to its simplicity, stability and less maintenance $[1,2]$

Commercial anodes are either aluminum or zinc alloys for marine applications. Aluminum anodes have reliable long-term performance, and also has better current and weight characteristics than zinc anode. Aluminum anodes can be improved the performance by controlling alloy composition. Al-Zn-In, $\mathrm{Al}-\mathrm{Zn}-\mathrm{Mg}$ and $\mathrm{Al}-\mathrm{Zn}-\mathrm{Sn}$ alloys are commonly used as sacrificial anodes in marine environments [3-6].

This paper is only concerned with the behaviour

Paper Received March, 1996. Revised June, 1996. Accepted June, 1996. Author for Correspondence: Tai-Ming Tsai.

* Lecturer, Department of Marine Engineering and Technology, National

Taiwan Ocean University, Keelung, Taiwan 20224, R.O.C. of several Al-Zn-In alloys used as anodes for cathodic protection in seawater. The effective cathodic protection potentials and protective area ratio of steel to sacrificial anode were also determined.

\section{EXPERIMENTAL PROCEDURE}

\section{Performance Measurement}

Cylindrical anodes $10 \mathrm{~cm}$ high and $2 \mathrm{~cm}$ in diameter with nominal compositions are listed in Table 1. All these cylindrical specimens were cast in steel mold, machined and polished with 600 grit emery paper, washed in acetone and quickly cleaned in a mixture of $2 \%$ chromic acid and $5 \%$ phosphoric acid at $80^{\circ} \mathrm{C}$.

The performance tests for aluminum anodes were conducted by the standard method of the Japan Society of Corrosion Engineering [7]. Test specimens were covered with anti-acid tape except an exposed area of $20 \mathrm{~cm}^{2}$. The stainless steel cathode with an exposed area of $300 \mathrm{~cm}^{2}$ was immersed in the one liter test cell. ASTM D 1141-75 artificial seawater was used to evaluate the performance of aluminum anodes in terms of open circuit potential (V,SCE), current capacity $(\mathrm{Ah} / \mathrm{kg})$ and current efficiency (\%). A Nichia Model G1001E galvanostat was used, and the current density was maintained at 1 $\mathrm{mA} / \mathrm{cm}^{2}$ at $25 \pm 1^{\circ} \mathrm{C}$ for 240 hours. After test, the corroded specimens were removed and chemically cleaned in a mixture at $2 \%$ chromic acid and $5 \%$

Table 1. Nominal Chemical Compositions of Aluminum Alloy Anodes (wt\%)

\begin{tabular}{cccccc}
\hline Designation & $\mathrm{Zn}$ & $\mathrm{In}$ & $\mathrm{Si}$ & $\mathrm{Fe}$ & $\mathrm{Al}$ \\
\hline Alloy A & 3.5 & 0.01 & 0.04 & 0.05 & Balance \\
Alloy B & 3.5 & 0.03 & 0.04 & 0.05 & Balance \\
Alloy C & 3.5 & 0.05 & 0.04 & 0.05 & Balance \\
Alloy D & 2.0 & 0.03 & 0.04 & 0.05 & Balance \\
Alloy E & 5.0 & 0.03 & 0.04 & 0.05 & Balance \\
\hline
\end{tabular}


phosphoric acid at $80^{\circ} \mathrm{C}$, and followed by rinsing in distilled water. Each individual specimen was weighed, and the current capacity and current efficiency were calculated [6]. The open circuit potentials of aluminum anodes were measured with respect to a saturated calomel electrode (SCE).

\section{Galvanic Coupling Measurement}

Cathodic protection is widely used to prevent or reduce the corrosion rate of marine structures. The aluminum alloy sacrificially corrodes to protect the steel structures, while it cathodically polarizes the steel to a potential below that of steel's open circuit potential. An applied potential must be adequate, otherwise the steel will be corroded or overprotected. In some cases, the large cathodic overvoltage will impair the mechanical properties [8] of the steel. The potential of steel specimen $(3 \mathrm{~cm} \times 3 \mathrm{~cm})$ was maintained at the chosen value with a Nichia model G1001E potentiostat in artificial seawater at $25 \pm 1^{\circ} \mathrm{C}$ for 240 hours. After test, the steel specimen was re-moved and chemical cleaned in a mixture of $1 \mathrm{~g} / 1$ hexamenthylenetetramine and $10 \%$ chloric acid, and followed by rinsing distilled water, Each individual specimen was weighed, and the corrosion rates of mild steel at various cathodic potentials can be calculated.

The materials chosen for galvanic couple experiments were alloy $\mathrm{C}$ and mild steel. The nominal compositions of he steel are $0.05 \% \mathrm{C}, 0.21 \% \mathrm{Si}$, $0.23 \% \mathrm{Mn}, 0.01 \% \mathrm{P}$, and $0.01 \% \mathrm{~S}$. Alloy $\mathrm{C}$ were cast, cut into flat coupons and contacted with a steel plate. The surface area of Alloy C contact with the test solution was varied from 0.30 to $38.8 \mathrm{~cm}^{2}$. One side and all edges of steel cathode were also covered with anti-acid tape, the exposed area of steel is $34 \mathrm{~cm}$ $\times 41 \mathrm{~cm}$. The area ratios of the steel to Alloy $\mathrm{C}$ were varied from $36: 1$ to $4647: 1$, and the equipotential plot on steel was measured with a potentiostat.

Specimens for polarization tests were initially stablized for 1 hour, and the polarization curves were determined at a scan rate of $0.1 \mathrm{mv} \mathrm{s}^{-1}$.

\section{RESULTS AND DISCUSSION}

\section{Performance Measurement}

The variations of open circuit potentials, current capacities and current efficiencies for five different aluminum anodes are listed in Table 2 . The stabilized open circuit potentials are in the range of $-1.07 \sim-1.13 \mathrm{~V}, \mathrm{SCE}$. The current capacity was calculated by dividing total accumulated current
Table 2. Results of Performance Test

\begin{tabular}{lccc}
\hline Designation & $\begin{array}{c}\text { Open Circuit } \\
\text { Potential } \\
\text { (V,SCE) }\end{array}$ & $\begin{array}{c}\text { Current } \\
\text { Capacity } \\
(\mathrm{Ah} / \mathrm{kg})\end{array}$ & $\begin{array}{c}\text { Current } \\
\text { Efficiency } \\
(\%)\end{array}$ \\
\hline Alloy A & -1.07 & 2590 & 88 \\
Alloy B & -1.11 & 2620 & 89 \\
Alloy C & -1.13 & 2680 & 91 \\
Alloy D & -1.11 & 2680 & 91 \\
Alloy E & -1.10 & 2600 & 89 \\
\hline
\end{tabular}

output by weight loss of the anode. The performance of aluminum anodes is strongly influenced by the addition of alloying elements. Results show that Al-3.5\%Zn-0.05\%In sacrificial anode (alloy C) has the best current capacity $(2680 \mathrm{Ah} / \mathrm{kg})$, current efficiency $(91 \%)$ and most negative open circuit potential (-1.13 V,SCE) among five tested alloys. Even small amount of indium in Al-Zn-In alloy is beneficial. The microstructure of alloy $\mathrm{C}$ is shown in Figure 1.

\section{Galvanic Coupling Measurement}

To ensure that the steel specimen can be protected, a series of tests were conducted at various potentials for 240 hours. The influence of applied cathodic potential on the corrosion rate of mild steel is shown in Figure 2. The error bars illustrate the variability of the data. It is clear from the figure that a corrosion rate of less than 1 mpy can be achieved with an applied potential of $-0.78 \mathrm{~V}, \mathrm{SCE}$. As the cathodic potential was increased, the corrosion rate decreased further, essentially reaching nil (undetectable weight loss) at $-1.1 \mathrm{~V}, \mathrm{SCE}$. The measured effective cathodic protection (e.g., less than 1 mpy) can be achieved at potentials quite

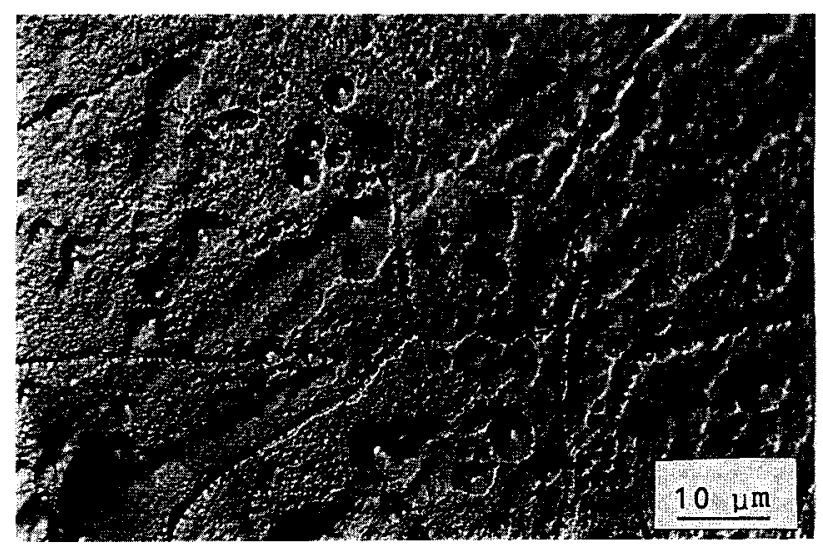

Fig. 1. Optical micrograph of alloy C. 
close to the $-0.850 \mathrm{~V}, \mathrm{Cu}-\mathrm{CuSO}_{4}$ reference electrode criterion [9]. It is also clear from Figure 2 that effective cathodic protection would be afforded to steel from a sacrificial anode capable of maintaining a coupled potential of $\sim-0.78 \mathrm{~V}, \mathrm{SCE}$. A corrosion rate under cathodic protection of $0.01 \mathrm{mpy}$ or less

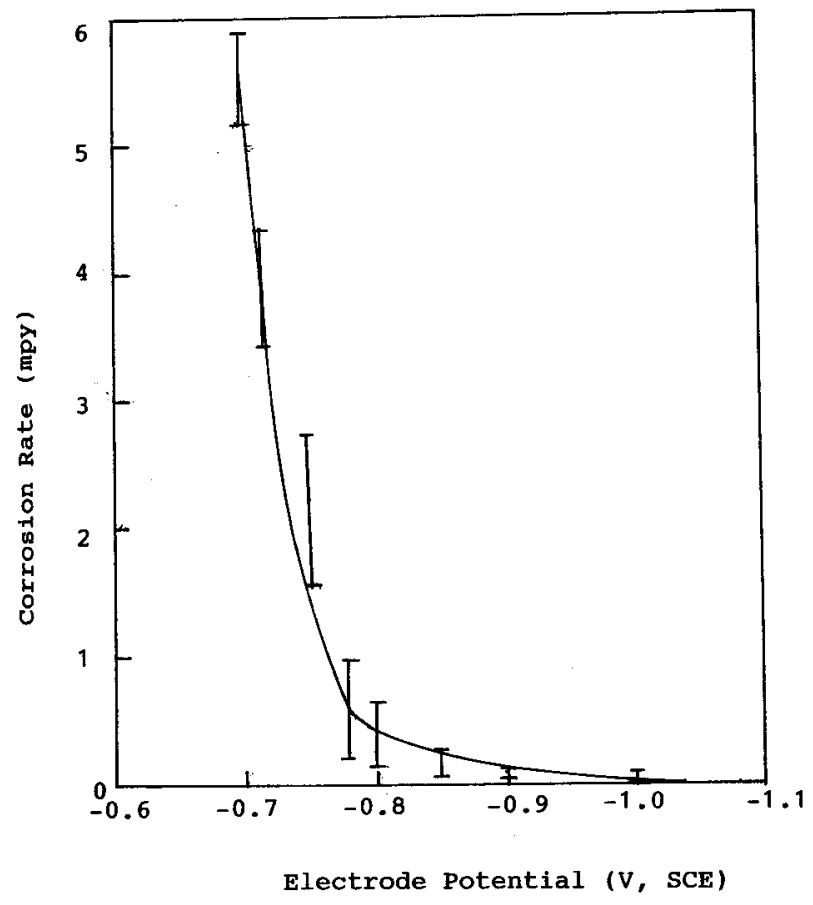

Fig. 2. Corrosion rate of mild steel in artificial seawater at $25^{\circ} \mathrm{C}$ as a function of cathodic potential.

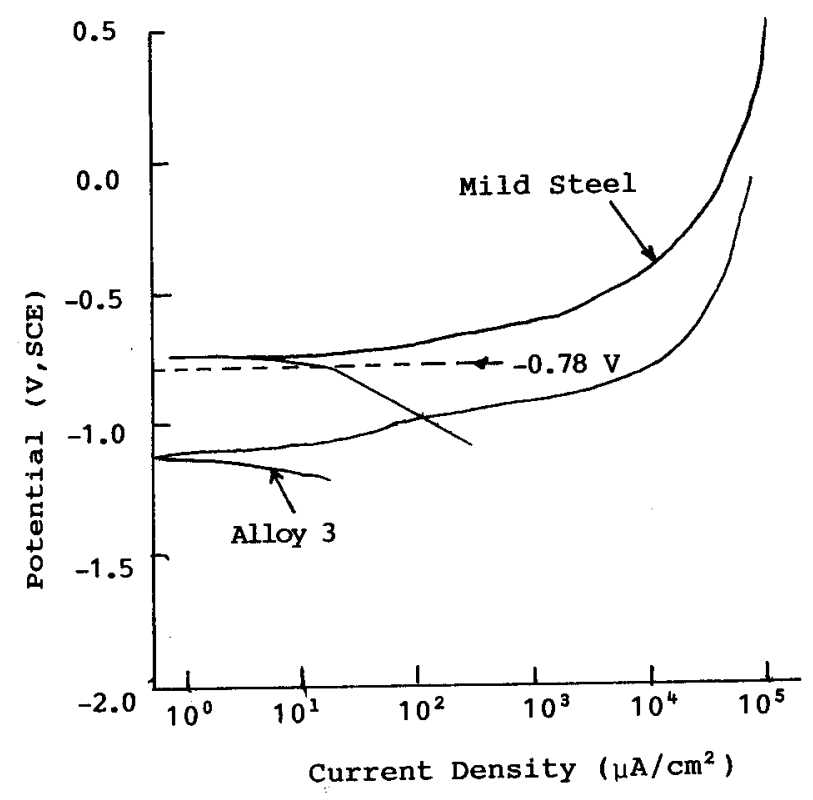

Fig. 3. Polarization curves for steel and alloy $\mathrm{C}$ in artificial seawater.

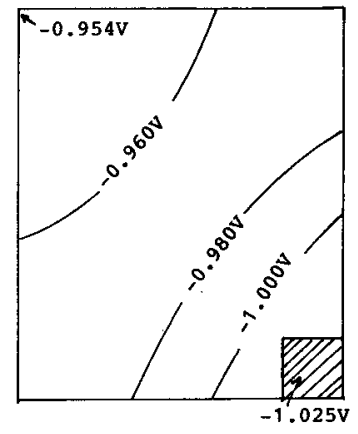

(a)

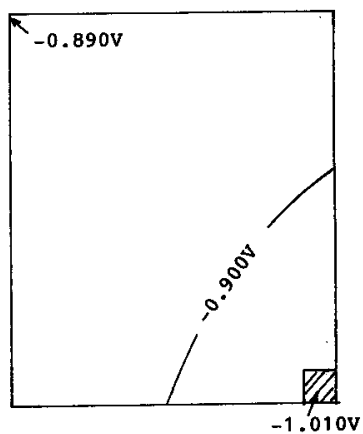

(c)

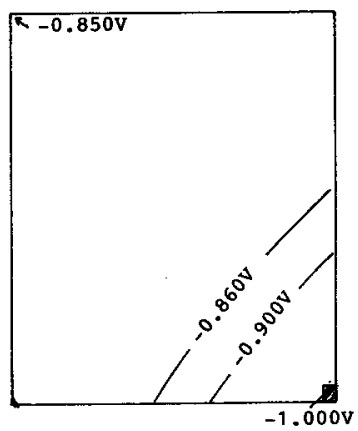

(e)

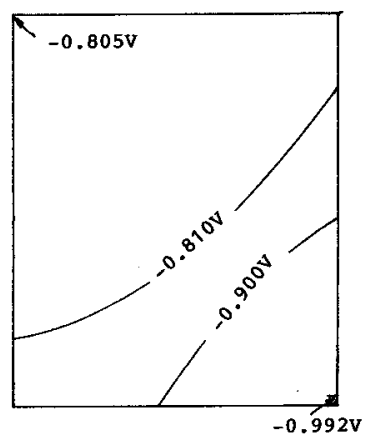

(g)

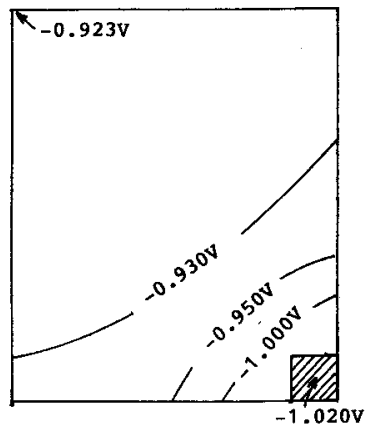

(b)

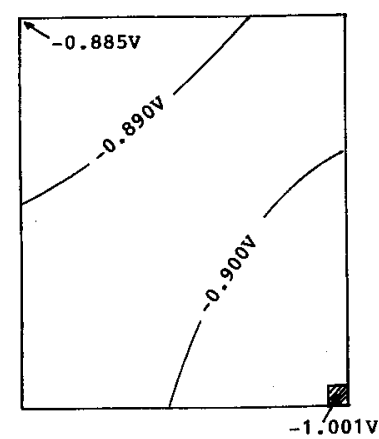

(d)

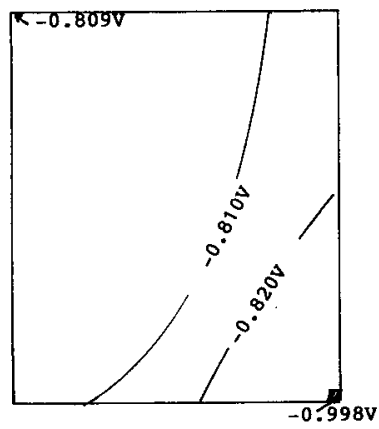

(f)

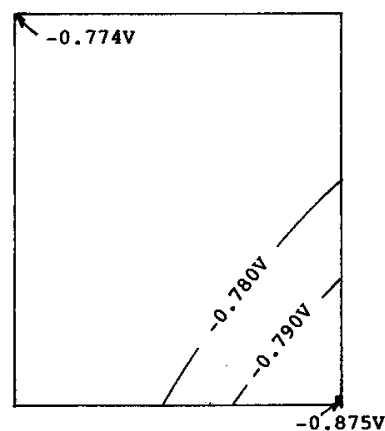

(h)
Fig. 4. Eequipotentidal distribution on steel, exposed area of steel is 34 $\mathrm{cm} \times 41 \mathrm{~cm}$ and exposed area of alloy $\mathrm{C}$ are
(a) 38.8
(b) 19.4
(c) 9.7
(d) 4.85
(e) 2.43
(f) 1.21
(g) 0.61
(h) $0.30 \mathrm{~cm}^{2}$
respectively. 
is admirable but may be wasteful as well [10]. The more active (negative) metal in a galvanic couple is anodically oxidized. Figure 3 shows the polarization curves of mild steel and alloy $\mathrm{C}$ in artificial seawater. No passive region was observed for alloy C. Thus, mild steel can be cathodically protected by installation of a sacrificial anode. Criteria for cathodic protection to a potential where Tafel behaviour achieved are also recommended by the National Association of Corrosion Engineering [9]. In this study, the measured effective cathodic potential at $-0.78 \mathrm{~V}, \mathrm{SCE}$, is just located within the cathodic Tafel region in Figure 3.

Using the above measured value of cathodic potential as a criterion for protection, a systematic study at the protecting area ratio of steel to sacrificial anode was conducted in artificial seawater. Flat specimens of steel were electrically contacted to various size of alloy $\mathrm{C}$ to determine the protective area ratio of steel to alloy $C$. The area ratio of steel to alloy $C$ is varied from $36: 1$ to $4647: 1$. The coupled potential contours on steel were determined and shown in Figure 4(a)-(h). alloy $C$ is coupled on the corner of steel specimen. The coupled potential on the alloy $\mathrm{C}$ shows much more negative than that on the opposite corner. The least negative coupled potential on the steel at various area ratios of steel to alloy $\mathrm{C}$ is shown in Figure 5. It is clear from Figure 5 that a protective area ratio can be up to $4000-5000$ with a coupled potential of $-0.78 \mathrm{~V}, \mathrm{SCE}$.

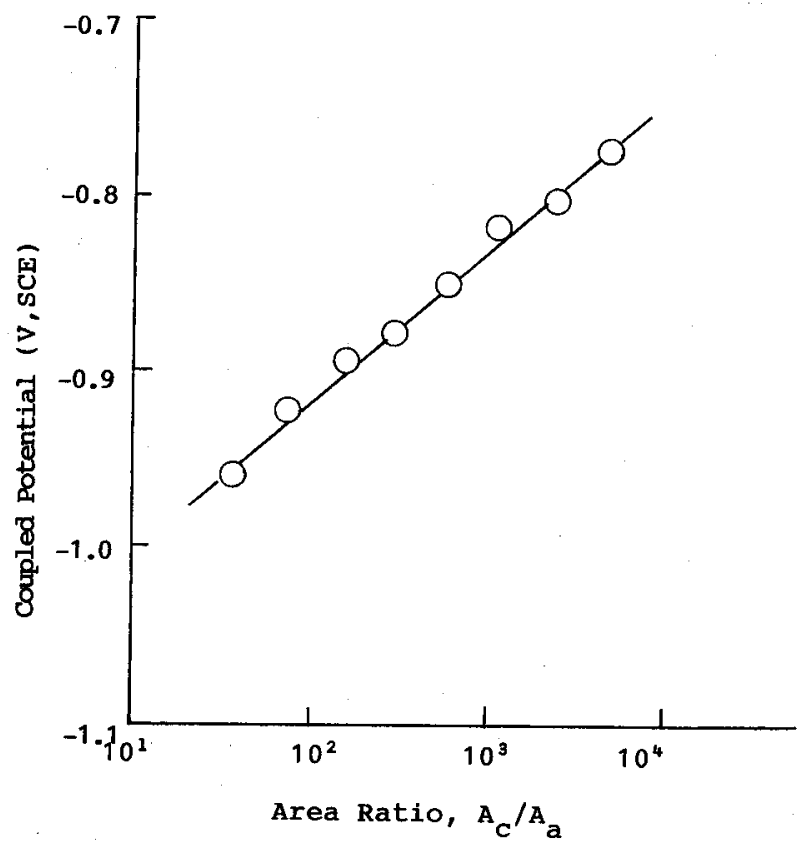

Fig. 5. The least negative coupled potential on steel as a function of steel to alloy $\mathrm{C}$ area ratio in artificial seawater at $25^{\circ} \mathrm{C}$.

\section{CONCLUSIONS}

On the basis of the data presented, the following conclusions can be drawn:

1. The performance of aluminum anodes is strongly influenced by the type and concentration of the alloying elements. Even small amount of In $(0.05 \%)$ in Al-Zn-In alloy is very beneficial.

2 . The effective cathodic protection potential determined for mild steel in artificial seawater was $-0.78 \mathrm{~V}, \mathrm{SCE}$.

3 . The above critical cathodic protection potential can be used as a criterion to design the protective area of steel structures.

\section{ACKNOWLEDGEMENT}

The author is grateful to Professor J. K. Wu for his kindness instruction in these years, and also thanks for his counseling in this paper.

\section{REFERENCES}

1. J.D. Gleason, Materials Performance, 17, 9 (1978).

2. R.L. Kean, L. Woolf and M.E. Beardsley,Metals and Materials, 6, 792 (1990).

3. R.H.Heidersbach, R. Baxter, J.S. Smart and M. Haroun; The Metal Handbook, 9th. Edition, Vol. 13, (Metals Park, OH; ASM, 1988), p. 921.

4. J.B. Bessone, R.A. Suorez Baldo and S.M. De De Micheli; Corrosion, 37, p. 533 (1981).

5. J.C. Lin and H.C. Shih; J. Electrochem. Soc., 134, p. 817 (1987).

6. T. Kobayashi and Y. Tamura, "Performance of New Aluminum Alloy Anodes in Sea Water Environments," 4th. Asian-Pacific Corrosion Control Conference, Vol. 1, p. 1, in Tokyo, Japan (1985).

7. Japan Society of Corrosion Engineering, Boshoku Gijutsu, 31, p. 612 (1982).

8. A. Oni and J.T. Ashaolu, Corrosion Prevention and Control, 38, p. 20 (1991).

9. Control of External Corrosion on Underground or Submerged Metallic Piping Systems, NACE Standard Rp-01-69, NACE, Houston (1983).

10. D.A. Jones, Principles and Prevention of Corrosion, Macmillan Publishing Company, New York, p. 437. 
海洋環境中使用鋁犠牲陽極保護銅

$$
\text { 材之研究 }
$$

蔡台明

國立台灣海洋大學輪機工程技術系

\section{摘 要}

本研究討論鉊、锌合金製作的傤牲陽極用於 㓌極保護的性狀; 結果顯示：合金C(Al-3.5\%Zn$0.05 \% \mathrm{In})$ 之珷牲陽極, 在五種Al-Zn-In合金中有最 佳的電流效率、最大的電流容量與最負之開路電 位, 極化曲線圆中影示: 合金C在人工海水中亦無 鈍化行為發生。軟銅在人工海水之腐蝕速率可由所 施加之㓌極電位決定, 亦即雨者呈一簡單函数; 由 圆2知, 㓌極保護電位在 $-0.78 \mathrm{~V}, \mathrm{SCE}$ 時, 軟鋼在海 水之腐蝕速率低於 $1 \mathrm{mpy}$ 。保護面積比量测結果败 示, 銅材與陽極面積比大至4000-5000時仍可被鉊 陽極保讙。 